\title{
Analiza mikropaskowego czujnika naprężeń z prostokątnym promiennikiem
}

\author{
Analysis of rectangular microstrip strain sensor
}

\section{Streszczenie}

Przetworniki mikropaskowe umożliwiają monitorowanie odkształcenia i pośrednio naprężenia badanego elementu konstrukcyjnego. Określenia odkształceń dokonuje się poprzez pomiar charakterystyki współczynnika odbicia $S_{11}$ w funkcji częstotliwości. Czujniki tego rodzaju wykazują liniową zależność zmian częstotliwości rezonansowych od wydłużenia badanego elementu, tak więc mogą być dobrą alternatywą dla tensometrów. W artykule zbadano, stosując metodę elementów skończonych, jak czułość przetwornika zależy od jego rozmiaru.

Słowa kluczowe: antenowy czujnik mikropaskowy; pomiar odkształceń; technika mikrofalowa; badania nieniszczące; SHM

\begin{abstract}
Microstrip sensors allow measurement of deformation and indirectly stress of construction element. Evaluation of deformation is done by measuring the characteristics of the reflection coefficient $S_{11}$ as a function of frequency. This kind of sensor has a linear dependence between the shift of the resonant frequency and strain, so, it can be alternative for strain gauges. In this article the dependence between the sensitivity of the sensor and its size was examined using Finite Element Modeling.
\end{abstract}

Keywords: microstrip antenna sensor; deformation measurement; microwave technique; nondestructive testing; SHM

\section{Wstęp}

Jednym z najważniejszych parametrów, które należy rozważyć przy projektowaniu konstrukcji jest jej potencjalna długość użytkowania. Zadanie to jest trudne ze względu na brak możliwości dokładnej oceny warunków pogodowych, zmienność obciążenia struktury, a także różnic w jakości wykonania. Przy projektowaniu zakłada się pewne wartości szacunkowe, które mogą okazać się zawyżone lub zaniżone. Aby zapewnić bezpieczeństwo podczas eksploatacji samolotów czy obiektów użytku cywilnego stosuje się badania nieniszczące (ang. Nondestructive testing). W dzisiejszych czasach coraz częściej okresowe inspekcje stanu konstrukcji zastępowane lub wspomagane są przez systemy structural health monitoring (SHM). Jest to spowodowane skomplikowanymi procedurami oraz wysokimi kosztami utrzymania. Najważniejszą zaletą techniki SHM jest możliwość monitorowania obiektu w czasie rzeczywistym, poprzez odpowiednio wczesną detekcję zmian parametrów mających wpływ na właściwości konstrukcji. Dzięki temu można zmniejszyć koszty naprawy uszkodzonej struktury lub całkowicie zapobiec awarii poprzez wykonanie odpowiednich czynności np. usunięcie nadmiaru śniegu z dachu. Ponadto, systemy tego typu mogą sprawdzić i poinformować o stanie konstrukcji po niebezpiecznych anomaliach pogodowych takich jak huragany, trzęsienia ziemi lub obfite opady śniegu [1,2]. Typowy system SHM składa się z: czujników, jednostki obliczeniowej oraz algorytmów umożliwiających detekcję, identyfikację oraz predykcję rozwoju uszkodzeń mogących spowodować niebezpieczeństwo, w trakcie dalszego funkcjonowania obiektu w tym stanie. W przypadku samolotów technika ta nie tylko pozwala zapewnić większe bezpieczeństwo, ale również zmniejszyć koszty konserwacji, obniżyć masę maszyny, zmniejszyć liczbę przeglądów oraz skrócić ich czas, dzięki czemu zmniejsza się także czas postojów [3].

Czujniki do monitorowania stanu odkształceń/naprężeń odgrywają kluczową rolę w monitorowaniu stanu konstrukcji. W przypadku systemów SHM mostów, co drugi użyty sensor kontroluje te parametry [10]. W ostatnich latach pojawił się pomysł wykorzystania czujników mikropaskowych do pomiaru odkształceń i pośrednio naprężeń [4\%17]. Czujniki tego typu są niczym innym jak antenami mikropaskowymi wykorzystywanymi choćby w telefonach komórkowych. Jednak w przypadku anten mikropaskowych wykorzystywanych do wykrywania odkształceń priorytetowe są inne parametry niż w przypadku zastosowań telekomunikacyjnych. Pomiaru odkształceń dokonuje się poprzez określenie charakterystyki częstotliwościowej współczynnika odbicia $\mathrm{S}_{11}$, za pomocą wektorowego analizatora sieci (VNA). Czujniki tego typu przykleja się w newralgicznych miejscach konstrukcji, a odkształcenia struktury powodują zmianę geometrii

Dr inż. Przemysław Łopato, mgr inż. Michał Herbko - Zachodniopomorski Uniwersytet Technologiczny w Szczecinie.

Autor korespondencyjny/Corresponding author: michal.herbko@zut.edu.pl 
promiennika sensora, a tym samym na zmianę rozpływu prądów w promienniku. Rozkład prądu w rezonatorze jest ściśle powiązany z częstotliwością rezonansową przetwornika $f_{r}$, tak więc zmiana geometrii promiennika wpływa na zmianę jego częstotliwości rezonansowej. Czujniki mikropaskowe mogą mieć taką samą budowę jak zwykłe anteny mikropaskowe, czyli z jednej strony dielektrycznego substratu rezonator, a z drugiej płaszczyznę masy. W przypadku monitorowania stanu elementów przewodzących płaszczyzna masy może być pominięta, rolę jej przejmie badany przewodzący element. Taka konfiguracja czujnika daje dodatkową funkcjonalność, jaką jest monitorowanie stanu pęknięć. Jednoczesne monitorowanie obu parametrów jest jednak niebezpieczne, ponieważ pęknięcie zdecydowanie mocniej wpływa na zmianę częstotliwości rezonansowej. Problem jednoczesnego pomiaru naprężeń i pęknięć jednym czujnikiem tego rodzaju został rozwiązany w pracy [14]. W zaproponowanym rozwiązaniu jeden rezonans wykorzystywany był do pomiaru pęknięcia, a drugi do pomiaru naprężenia.

Czujniki tego rodzaju wykazują liniową zależność zmian częstotliwości rezonansowych od wydłużenia badanego elementu, więc stają się alternatywą dla tensometrów. Porównując oba typy przetworników można stwierdzić, że:

- mikropaskowy czujnik naprężeń w przeciwieństwie do tensometrów, daje możliwość dodatkowego monitorowania stanu pęknięć w elementach przewodzących [8];

- częstotliwość rezonansowa może być mierzona bezprzewodowo, natomiast tensometr wymaga modułu do bezprzewodowego przesyłania danych [5];

- antena mikropaskowa daje możliwość multipleksowania, dzięki czemu można utworzyć dużą sieć czujników, która zapewni pokrycie dużej powierzchni, natomiast multipleksowanie czujników tensometrycznych jest trudniejsze [5].

Do pomiarów odkształceń i pośrednio naprężeń stosuje się promienniki o różnym kształcie. Najpopularniejszym jest sensor z promiennikiem w kształcie prostokąta $[5 \div 7,11 \div 13]$. Przetwornik ten jest bardzo czuły, kiedy siła działa na czujnik w kierunku równoległym do osi promiennika, natomiast w kierunku prostopadłym czułość jest zdecydowanie mniejsza. Podobne wyniki otrzymano stosując czujnik z rezonatorem w kształcie koła [4]. Jednym z rozwiązań tego problemu jest pomiar dwóch częstotliwości rezonansowych sensorem z promiennikiem w kształcie prostokąta [12]. Taki sposób pomiaru eliminuje problem opisany powyżej, ponieważ pierwsza częstotliwość rezonansowa zmienia się bardziej dla naprężeń działających w kierunku równoległym do osi promiennika, natomiast druga częstotliwość rezonansowa jest bardziej czuła na siły działające prostopadle do osi promiennika. W tej metodzie pomiarowej trzeba monitorować szerszy zakres częstotliwości, przez co liczba punktów pomiarowych ulega zwiększeniu, w wyniku czego potrzebny jest analizator o większym zakresie częstotliwości, a także może wystąpić potrzeba zwiększenia kroku pomiarowego, ze względu na ograniczoną liczbę punktów pomiarowych VNA. W $[9,10,17]$ zaprezentowano czujniki o innych, bardziej skomplikowanych kształtach. Charakteryzowały się również liniową zmianą częstotliwości rezonansowej pod wpływem obciążenia, były jednak czułe w kierunku prostopadłym, jak i równoległym do osi promiennika.

W niniejszej pracy zbadane zostały zmiany częstotliwości rezonansowej dla przetworników z promiennikami w kształcie prostokąta o różnej częstotliwości operacyjnej. Dla jednakowego poziomu naprężeń blachy ze stali konstrukcyjnej wyznaczono charakterystykę zmian częstotliwości rezonansowych $\Delta \mathrm{f}_{\mathrm{r}}$ od częstotliwości rezonansowych $\mathrm{f}_{\mathrm{r}}$ czujników. Przeprowadzona analiza miała na celu określenie wpływu rozmiarów przetwornika (pośrednio częstotliwości operacyjnej) na jego czułość.

\section{Projekt czujników}

Podczas procesu projektowania przetwornika można wykorzystać następujące metody: model linii transmisyjnej, model wnękowy, model pełnofalowy, metodę elementów skończonych (FEM) i metodę różnic skończonych (FDTD). Wymiary czujników zostały wyznaczone za pomocą modelu linii transmisyjnej (rys. 1). Na potrzeby przeprowadzonej analizy zaprojektowano 18 czujników w zakresie częstotliwości $0,5 \div 15 \mathrm{GHz}$, za pomocą następujących zależności [18]: - szerokość promiennika czujnika W:

$$
W=\frac{c}{2 \cdot f_{r}} \sqrt{\frac{2}{\varepsilon_{r}+1}}
$$

- efektywna przenikalność elektryczna $\varepsilon_{\text {reff }}$ promiennika:

$$
\varepsilon_{\text {reff }}=\frac{\varepsilon_{r}+1}{2}+\frac{\varepsilon_{r}-1}{2}\left\lfloor 1+12 \cdot \frac{h}{W}\right\rfloor
$$

- długość skrócenia $\Delta \mathrm{L}$ :

$$
\Delta L=h \cdot 0,412 \cdot \frac{\left(\varepsilon_{\text {reff }}+0,3\right) \cdot\left(\frac{W}{h}+0,264\right)}{\left(\varepsilon_{\text {reff }}-0,258\right) \cdot\left(\frac{W}{h}+0,8\right)}
$$

- długość promiennika L:

$$
L=\frac{\lambda}{2}-2 \cdot \Delta L
$$

- długość wcięcia dopasowującego impedancję promiennika do linii mikropaskowej $\mathrm{y}_{0}$ :

$$
y_{0}=\frac{L}{\pi} \cdot \arcsin \left(\sqrt{\frac{Z_{0}}{R_{i n}}}\right)
$$

gdzie:

c - prędkość światła w próżni,

$\mathrm{f}_{\mathrm{r}}$ - częstotliwość rezonansowa anteny,

$\varepsilon_{\mathrm{r}}$ - przenikalność względna laminatu,

$\mathrm{h}$ - grubość laminatu,

$\lambda$ - długość fali,

$Z_{0}$ - projektowana impedancja promiennika,

$\mathrm{R}_{\text {in }}$ - rezystancja promiennika bez wcięcia.

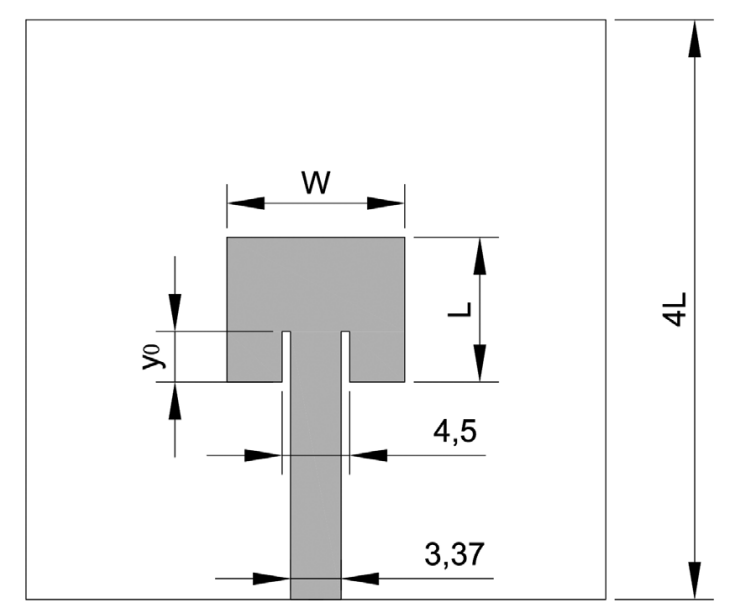

Rys. 1. Wymiary czujnika, w mm

Fig. 1. Dimensions of the sensor, in $\mathrm{mm}$ 
W tablicy I zaprezentowane zostały wymiary zaprojektowanych czujników. Do analizy wybrano laminat mikrofalowy ROGERS RT5880 $\left(\varepsilon_{\mathrm{r}}=2,2\right)$ o grubości $0,787 \mathrm{~mm}$, który jest bardzo elastyczny (moduł Younga $E=1,070 \mathrm{GPa}$ ), dzięki czemu sensor w bardzo niewielkim stopniu mechanicznie wpływa na element badany.

Tablica I. Wymiary zaprojektowanych czujników Table I. Dimensions of the designed sensors

\begin{tabular}{|c|c|c|c|}
\hline $\mathrm{f}[\mathrm{GHz}]$ & $\mathrm{W}$ [mm] & L [mm] & $\mathrm{y}_{0}[\mathrm{~mm}]$ \\
\hline 0,5 & 237,17 & 201,96 & 71,066 \\
\hline 1 & 118,59 & 100,82 & 35,465 \\
\hline 1,5 & 79,057 & 67,096 & 23,595 \\
\hline 2 & 59,293 & 50,23 & 17,657 \\
\hline 2,5 & 47,434 & 40,107 & 14,094 \\
\hline 3 & 39,528 & 33,355 & 11,716 \\
\hline 4 & 29,646 & 24,909 & 8,743 \\
\hline 5 & 23,717 & 19,836 & 6,956 \\
\hline 6 & 19,764 & 16,45 & 5,763 \\
\hline 7 & 16,941 & 14,029 & 4,91 \\
\hline 8 & 14,823 & 12,21 & 4,27 \\
\hline 9 & 13,176 & 10,794 & 3,771 \\
\hline 10 & 11,859 & 9,661 & 3,371 \\
\hline 11 & 10,78 & 8,732 & 3,044 \\
\hline 12 & 9,882 & 7,957 & 2,771 \\
\hline 13 & 9,122 & 7,3 & 2,539 \\
\hline 14 & 8,47 & 6,737 & 2,341 \\
\hline 15 & 7,906 & 6,249 & 2,169 \\
\hline
\end{tabular}

\section{Analiza numeryczna}

Dla przetworników zaprojektowanych z wykorzystaniem modelu linii transmisyjnej wykonano analizę metodą FEM. Obliczenia zostały wykonane za pomocą oprogramowania COMSOL Multiphysics 5.2., które umożliwia symulacje odkształcania elementu badanego, poprzez użycie modułu mechanicznego (Solid Mechanics) i następnie wykonywanie obliczeń elektromagnetycznych wysokiej częstotliwości (RF Module), a zatem badanie charakterystyki współczynnika odbicia $S_{11}$ mikropaskowego czujnika naprężeń przytwierdzonego do obciążanego elementu.

W tym celu zbudowany został model przedstawiony na rysunku 2. Zaprojektowane czujniki przytwierdzane były do blachy ze stali S355J2+n o grubości $2 \mathrm{~mm}$. Stal tego rodzaju stosuje się m.in. w konstrukcjach mostów. Blacha ta miała kształt kwadratu o długości boku równego 7L, takie skalowanie zapewnia zachowanie takiego samego wpływu sensora na stopień rozciągnięcia elementu badanego. Z drugiej strony przytwierdzono taki sam laminat, który uwzględniono przy projektowaniu czujników, aby uniknąć wygięcia płyty stalowej. Jedna krawędź blachy została unieruchomiona, a przeciwległa obciążona siłą, aby uzyskać naprężenie równe $350 \mathrm{MPa}$, jak pokazano na rysunku 3. Na rysunku 4 przedstawiono przemieszczenie wywołane działaniem zadanego wymuszenia.

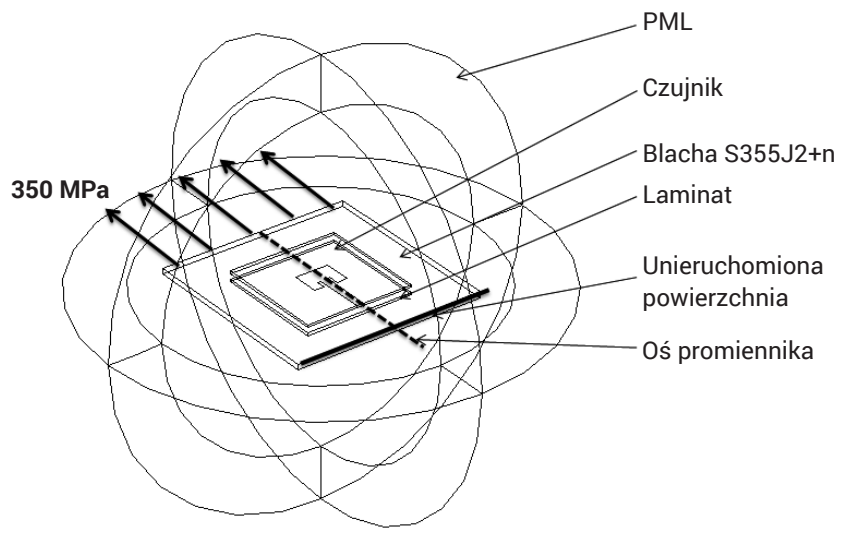

Rys. 2. Model wykorzystywany podczas analizy numerycznej Fig. 2. Model used in numerical analysis

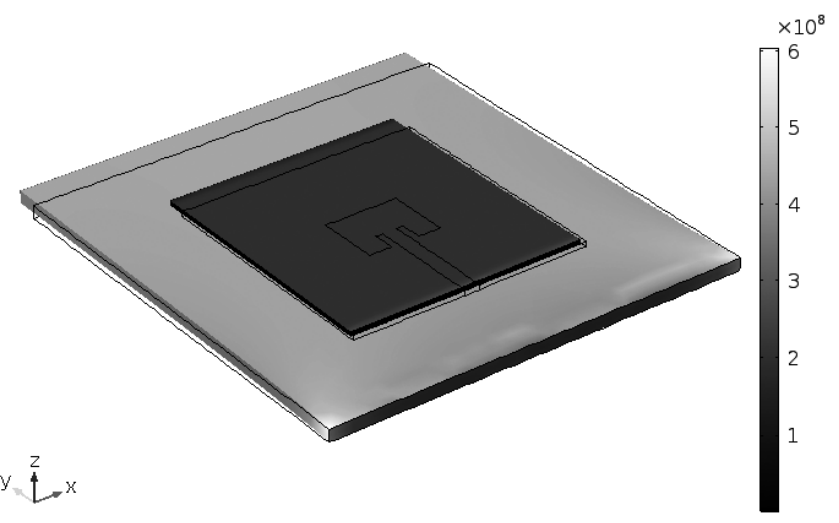

Rys. 3. Obliczony rozkład naprężenia, w $\mathrm{Pa}$

Fig. 3. Calculated stress distribution, in $\mathrm{Pa}$

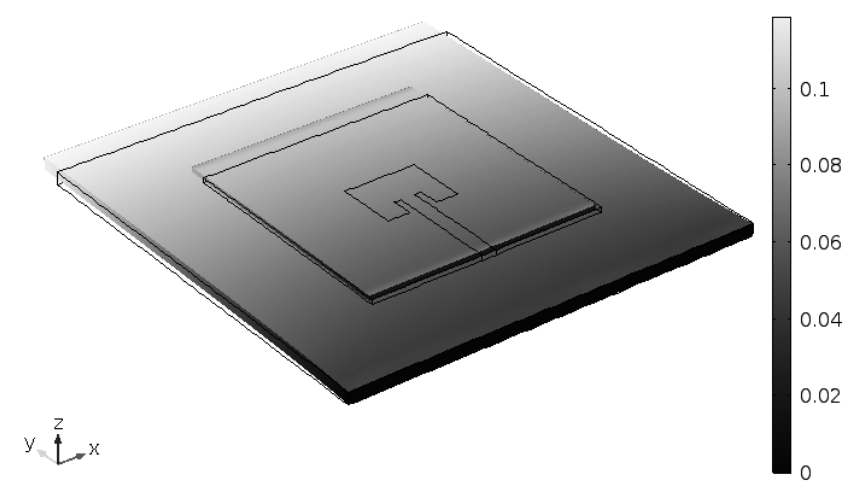

Rys. 4. Przemieszczenie, $\mathrm{w} \mathrm{mm}$

Fig. 4. Displacement, in $\mathrm{mm}$

Wokół antenowego czujnika naprężeń zostały wprowadzone dwie sfery. Wewnętrzna sfera pełni rolę otoczenia przetwornika - umożliwia wypromieniowanie i propagację fali elektromagnetycznej. Zewnętrzna powłoka stanowi przestrzeń absorbującą (PML, ang. Perfectly Matched Layers) fale elektromagnetyczne wytwarzane przez przetwornik, ograniczając przestrzeń obliczeń. Mikropaskowy czujnik naprężeń umieszczony na stalowej blasze został umieszczony w centrum powyższych sfer. 
W modelu tym założono, że promiennik, linia mikropaskowa oraz masa są idealnymi przewodnikami, a substrat wykonany jest z laminatu ROGERS RT5880 o względnej przenikalności elektrycznej równej 2,2. Następnym uproszczeniem, jakiego dokonano, jest przyjęcie zerowej grubości płaszczyzny przewodzącej (w rzeczywistości rzędu $35 \mu \mathrm{m}$ ), aby uniknąć powstania dużej liczby elementów w tych miejscach.

Obliczenia wykonywane były z krokiem 0,1 MHz, aby zapewnić wysoką dokładność przy wyznaczaniu częstotliwości rezonansowej. Częstotliwość ta odpowiada minimum lokalnemu współczynnika $S_{11}$, który reprezentuje stosunek mocy sygnału odbitego do mocy sygnału wejściowego. Parametr ten wyznacza się w dziedzinie częstotliwości. Na rysunku 5 przedstawiono charakterystykę współczynnika $S_{11}$ czujnika zaprojektowanego na $10 \mathrm{GHz}$, jest to typowa charakterystyka dla anten mikropaskowych. Otrzymano nieco mniejsze niż zakładano częstotliwości rezonansowe. Efekt ten w proponowanej aplikacji nie ma większego znaczenia w przeciwieństwie do zastosowań telekomunikacyjnych, gdzie pasmo pracy jest ściśle zdefiniowane. Natomiast na rysunku 6 zilustrowano rozkład pola elektrycznego dla częstotliwości rezonansowej tego czujnika, z którego można wywnioskować, że prąd płynie równolegle do osi promiennika. Taki rozkład prądu zapewnia największą czułość na siły działające w kierunku równoległym do osi promiennika.

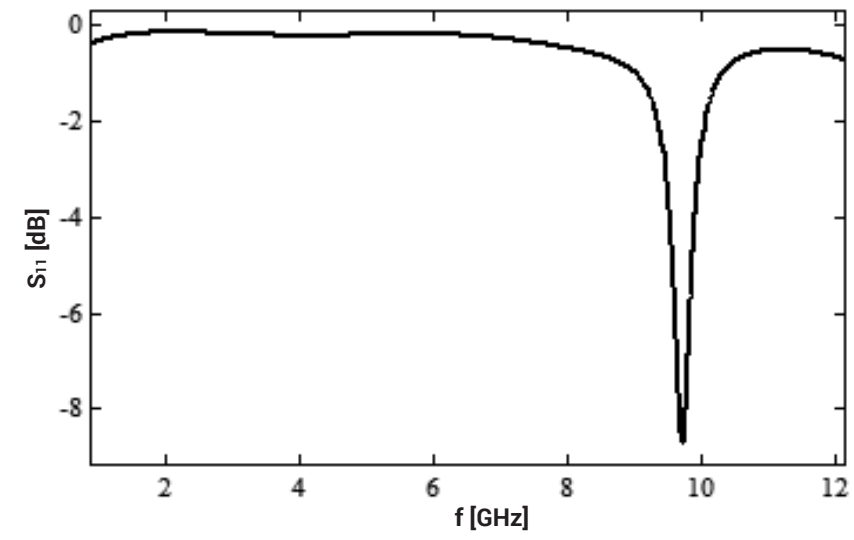

Rys. 5. Charakterystyka współczynnika odbicia $S_{11}$ czujnika zaprojektowanego na $10 \mathrm{GHz}$

Fig. 5. Frequency response of reflection coefficient $S_{11}$ in case of sensor designed for $10 \mathrm{GHz}$

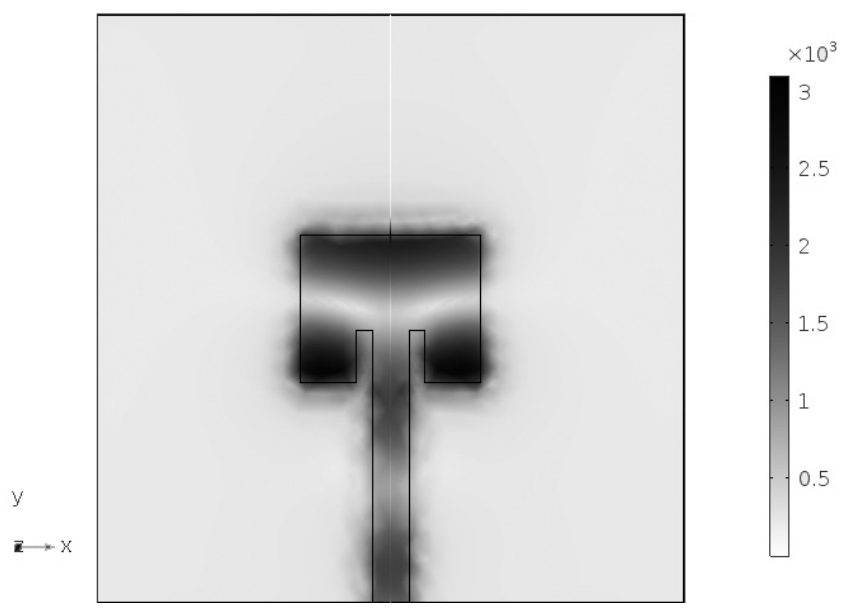

Rys. 6. Rozkład pola elektrycznego (V/m) dla częstotliwości rezonansowej czujnika zaprojektowanego na $10 \mathrm{GHz}$

Fig. 6. Distribution of the electric field $(\mathrm{V} / \mathrm{m})$ for the resonant frequency of the sensor designed at $10 \mathrm{GHz}$
W niniejszej pracy wykonano tylko obliczenia dla zerowego obciążenia oraz przy naprężeniu równym $350 \mathrm{MPa}$, ponieważ jak wykazano w $[5 \div 7,11,12]$, zmiana częstotliwości w funkcji obciążenia ma charakter ściśle liniowy, przy pomiarach wykonywanych do granicy plastyczności materiału. Przykładowe charakterystyki współczynnika odbicia dla różnych wartości naprężenia (0 i $350 \mathrm{MPa}$ ) zostały zaprezentowane na rysunku 7. Można na ich podstawie zauważyć, że częstotliwość rezonansowa sensora maleje wraz z obciążeniem. W pracy postanowiono zbadać wartości zmian częstotliwości dla przetworników zaprojektowanych na różną częstotliwość rezonansową, na rysunku 8 pokazano charakterystykę zmian częstotliwości dla różnych przetworników. Na podstawie, której wynika, że przetwornik o wyższej nominalnej częstotliwości rezonansowej charakteryzuje się większymi zmianami wartości $\Delta \mathrm{f}_{\mathrm{r}}$ a co za tym idzie większą czułością:

gdzie:

$$
\Delta f_{r}=f_{r 0 M P a}-f_{r 350 M P a}
$$

$\Delta \mathrm{f}_{\mathrm{r}}-$ zmiana częstotliwości rezonansowej;

$\mathrm{f}_{\mathrm{roMPa}}$ - częstotliwość czujnika przytwierdzonego do nieobciążonej próbki;

$\mathrm{f}_{\mathrm{r} 350 \mathrm{MPa}}$ - częstotliwość czujnika przytwierdzonego do próbki obciążonej.

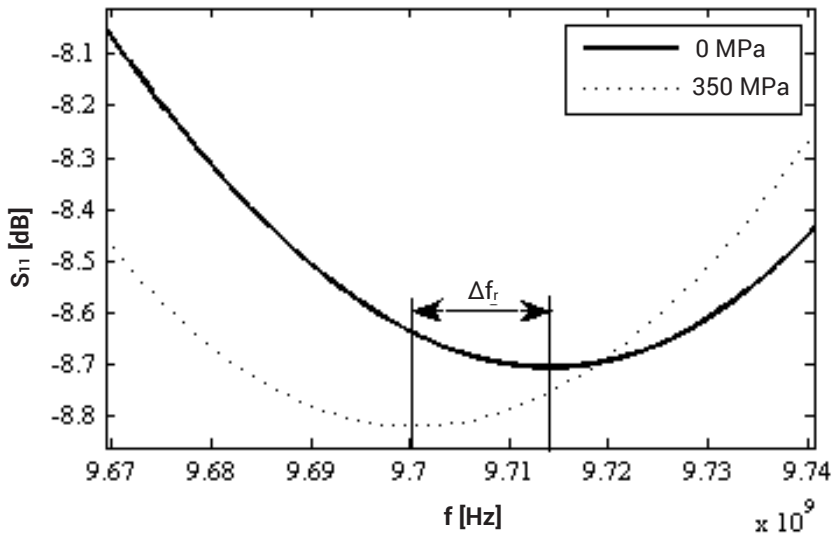

Rys. 7. Charakterystyki współczynnika $S_{11}$ w pobliżu częstotliwości rezonansowej dla przetwornika przymocowanego do nieobciążonej i obciążonej próbki $\left(\mathrm{f}_{\mathrm{r}} \cong 10 \mathrm{GHz}\right)$

Fig. 7. Frequency response for $S_{11}$ coefficient near the resonant frequency for sensor attached to an unloaded and loaded sample $\left(\mathrm{f}_{\mathrm{r}} \cong 10 \mathrm{GHz}\right)$

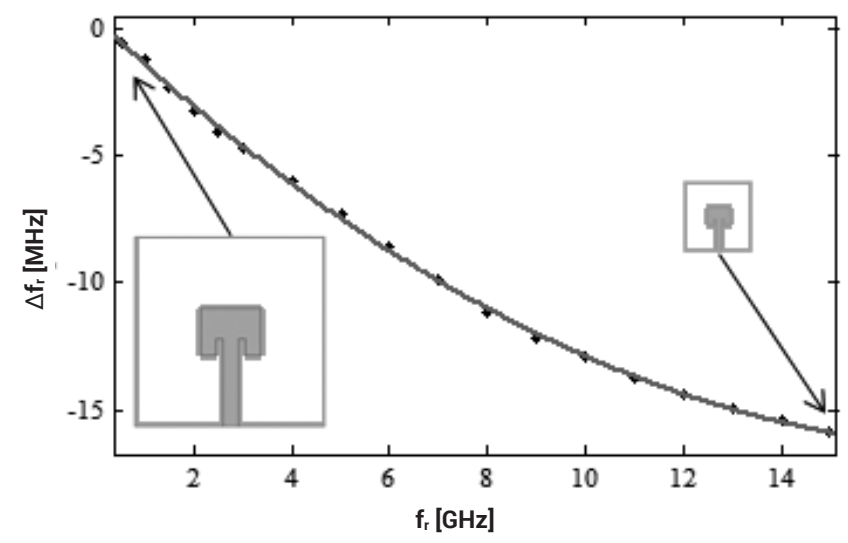

Rys. 8. Zależność $\Delta \mathrm{f}_{\mathrm{r}}$ od częstotliwości rezonansowej przetwornika (naprężenie $350 \mathrm{MPa}$ )

Fig. 8. Relation between $\Delta \mathrm{f}_{\mathrm{r}}$ and sensor resonant frequency (stress $350 \mathrm{MPa}$ ) 


\section{Podsumowanie}

W niniejszym artykule przeprowadzona została analiza czułości mikropaskowych czujników naprężeń z promiennikami w kształcie prostokąta o różnej nominalnej częstotliwości rezonansowej. Z przeprowadzonych badań wynika, że wartość zmian częstotliwości rezonansowych (proporcjonalna do czułości) rośnie wraz ze wzrostem częstotliwości rezonansowej przetwornika. Następną zaletą czujników o wyższym $\mathrm{f}_{\mathrm{r}}$ jest ich mniejszy rozmiar. Należy jednak zwrócić uwagę na wyższy koszt VNA, który umożliwia pomiar większego zakresu częstotliwości, co może znacząco zwiększyć koszt projektowanego systemu SHM. Obecny postęp w technologii mikrofalowych układów scalonych oraz ich masowa produkcja pozwalają zaryzykować stwierdzenie, że już wkrótce koszt systemu SHM wykorzystującego przetworniki mikropaskowe będzie konkurencyjny względem tradycyjnych układów tensometrycznych.

\section{Literatura}

[1] Y. Q. Ni, K. Y. Wong: Integrating Bridge Structural Health Monitoring and Condition-Based Maintenance Management, 4th International Workshop on Civil Structural Health Monitoring, 2012 Nov 6-8, Berlin, Germany.

[2] C. Ranieri, G. Fabbrocino, E. Cosenza: Structural health monitoring systems as a tool for seismic protection, The 14th World Conference on Earthquake Engineering, 2008 Nov 12-17, Beijing, China.

[3] C. Bockenheimer, H. Speckmann: Validation, Verification and Implementation SHM at Airbus, IWSHM, 2013, Standford, USA

[4] A. Daliri, A. Galehdar, S. John, C. H. Wang W. S. T. Rowe, Ghorbani K.: Wireless strain measurement using circular microstrip patch antennas, Sensors and Actuators A: Physical, vol. 184, pp. 86-92, 2012

[5] U. S. Tata: Study of patch antennas for strain measurement, Arlington, 2008.

[6] W. Wang, H. Ge , T. Liu T., Liu M.: Study of Patch Antennas for Strain Measurement, Electromagnetic Nondestructive Evaluation (XVIII), vol. 40, pp. 313-321, 2015.

[7] N. Sharama N., V. V. Thakare: Analysis of Microstrip Rectangular Patch Antenna as a Strain Sensor, International of Research in Electronic and Communication Technology, vol. 2, No. 2, pp. 17-19, 2015.

[8] H. Huang, Flexible: Wireless Antenna Sensor. A Review, IEEE Sensors Journal, vol. 13, No. 10, pp. 3865-3872, 2013.

[9] A.Daliri: Slotted circular microstrip antenna application in strain based structural health monitoring, The 14th Australian International Aerospace Congress, 2011 Feb 28-Mar 3: Melbourne, Australia.

[10] A. Daliri, C. H. Wang, S. John, A. Galehdar, W. S. T. Rowe, K. Ghorbani: Multidirectional circular microstrip patch antenna strain sensor, ASME 2011 Conference on Smart Materials, Adaptive Structures and Intelligent Systems, 2011 Sep 18-21, Scottsdale, USA.

[11] A. Benchirouf, R. Zichner, C. Muller, O. Kanoun: Electromagnetic Simulation of Flexible Strain Sensor based Microstrip Patch Antenna, International Journal of Microwave and Optical Technology, vol. 16, No. 6-I, pp. 397-401, 2015.

[12] U. Tata, H. Huang, R. L. Carter, Chiao J. C.: Exploiting a patch antenna for strain measurements, Measurement Science and Technology, vol. 20., No. 1, pp. 1-7, 2009.

[13] P. Lopato, G. Psuj, M. Herbko, M. Maciusowicz: Evaluation of stress in steel structures using electromagnetic methods based on utilization of microstrip antenna sensor and monitoring of AC magnetization process, IAPGOŚ, vol. 6, No. 4, pp. 32-36, 2016.

[14] G. Psuj, B.Szymanik, P. Lopato, M. Herbko, M. Maciusowicz: Wielomodalne monitorowanie postępu zmian zmęczeniowych w stalowych elementach konstrukcji, Przegląd Spawalnictwa, vol. 88, nr 10, s. 104-109, 2016.

[15] A. Daliri, A. Galehdar, W.S. Rowe, K. Ghorbani, S. John: Utilising microstrip patch antenna strain sensors for structural health monitoring, Journal of Intelligent Material Systems and Structures, vol. 23, No. 2, pp.169-182, 2011.

[16] X. Yi, T. Wu, Y. Wang, R.T. Leon, M.M. Tentzeris, G. Lantz: Passive Wireless Smart-Skin Sensor using RFID-Based Folded Patch Antenna, International Journal of Smart and Nano materials, vol. 2, No. 1, pp. 22-38, 2010.

[17] M. Herbko: Mikrofalowy czujnik do monitorowania stanu odkształceń w materiałach, Praca magisterska, Zachodniopomorski Uniwersytet Technologiczny w Szczecinie, Szczecin, 2016.

[18] C.A. Balanis: Antenna theory. third edition, John Wiley \& Sons, Hoboken, 2005. 